\title{
Radioecology: Why Bother?
}

\author{
Emily Amanda Caffrey*, Mary Elizabeth Leonard, Jonathan Bamberger Napier, Delvan Reed Neville, \\ Kathryn Ann Higley
}

Department of Nuclear Engineering and Radiation Health Physics, Oregon State University, Corvallis, USA.

Email: smitemil@onid.oregonstate.edu

Received December 21 $1^{\text {st }}, 2013$; revised January $19^{\text {th }}, 2014$; accepted February $15^{\text {th }}, 2014$

Copyright (C) 2014 Emily Amanda Caffrey et al. This is an open access article distributed under the Creative Commons Attribution License, which permits unrestricted use, distribution, and reproduction in any medium, provided the original work is properly cited. In accordance of the Creative Commons Attribution License all Copyrights (C) 2014 are reserved for SCIRP and the owner of the intellectual property Emily Amanda Caffrey et al. All Copyright (c) 2014 are guarded by law and by SCIRP as a guardian.

\section{ABSTRACT}

The importance of radioecology to the discussion of radioactive contamination is discussed here. This paper discusses the history of radioecology, alongside the most recent developments in the science. It describes the need for more environmental data, and explains where the gaps in current knowledge lie. The calculation of radiation dose to wildlife along with the complications in performing such calculations is discussed. The paper also tackles the difficult question of the implications of radioecology on nuclear waste management and site decommissioning policies. From the beginnings of the science to today, radioecology is poised to be an important field of study as humans continue to rely on ionizing radiation to improve their lives.

\section{KEYWORDS}

\section{Radioecology; Wildlife Dose Calculations; Nuclear Waste Disposal; Environmental Protection}

\section{Introduction: A Brief History of Radioecology}

"Radioecology is the study of behavior and effects of radioactive elements in the environment. This can be broken into three subdivisions: radionuclide movement within ecological systems and accumulation within specific ecosystems components such as soil, air, water, and biota; the effects of ionizing radiation on individual species, populations, communities, and ecosystems; and the use of radionuclides and ionizing radiation in studies of structure and function of ecosystems and their component subsystems” [1].

Radiation protection has historically focused on humans as the object of protection standards. In 1977, the International Commission on Radiological Protection (ICRP) stated that "Radiation protection has historically been solely focused on human protection, with the reasoning that... the level of safety required for the [radiation] protection of all human individuals is thought likely to be adequate to protect other species, although not necessarily individual members of these species. The Commission therefore believes that if man is adequately pro-

*Corresponding author. tected then other living things are also likely to be sufficiently protected” [2].

In 2008, ICRP recommendations shifted toward a new paradigm, one in which wildlife populations are considered to be their own protection endpoint. This decision has raised numerous challenges for the scientific community, and efforts are currently in progress to deepen the understanding of how radiation impacts non-human biota (NHB). With this new paradigm, evaluating radiation dose to biota in response to planned, existing, or emergency situations is of significant concern. As doseresponse relationships are not currently well understood for NHB, it is imperative to make an accurate determination of dose rates at which NHB are exposed.

This paper aims to place radioecology in the context of radiological contamination, with the intent to inform readers about this field of study and some of the ongoing work to improve radioprotection of the environment.

\section{The Need for More Data}

\subsection{Controversy and Data Gaps}

There is confusion over appropriate endpoints of protec- 
tion. For humans, we are interested in reducing the lifetime cancer risk to as low as reasonably achievable, a stochastic endpoint, as our radiation protection standards virtually rule out deterministic effects. The dose-response relationship for humans is assumed to be linear, with no threshold, meaning that any increase in dose is an increase in risk. The dose response relationship for NHB is unknown in many cases. Table 1 illustrates the differences in human and ecological protection.

There is also a scarcity of long-term multigenerational studies for NHB. One study shows that bank voles living in the Chernobyl exclusion zone had levels chromosomal aberrations in bone marrow that remained constant with each generation, despite decreasing levels of dose. In addition, the percent mortality of their embryos increased with time [3], suggesting that chronic, low doses of radiation may be more detrimental to organism health than previously assumed.

Finally, there is a growing abundance of data to challenge established paradigms. Several studies done by Møller and Mousseau in the Chernobyl region suggest that there may be population level effects at radiation doses below that which were previously assumed safe $[4,5]$. These studies challenge our belief that low levels of radiation (e.g., a few multiples of background dose rates) are essentially harmless to NHB. They highlight the need for a coordinated research effort to both qualify the types of effects and quantify their level of damage. There is ongoing research that is attempting to assist in the evaluation of radiation dose received by NHB. Table 2 provides a qualitative summary of the available data on chronic radiation effects [6].

\subsection{Source Validity}

It is generally taken as true that site specific analytical results are more representative of a location than generic data. Studies of analogues may be used for site analysis, but the information should be limited to parameter fitting [7]. Additionally, applying non site specific data can lead to less accurate results because radionuclide data is "influenced by many factors associated with the properties of the radionuclide, the organism, and the ecosystem. As a result, individual measurements display a great deal of variability [8].

An analysis of the source term data for the biosphere sub-model of Yucca Mountain by Higley et al. [9] determined that, of 538 parameters, 139 were sourced from

Table 1. Differences in human vs. ecological protection.

\begin{tabular}{|c|c|c|c|}
\hline & Observation Unit & Endpoint of Concern & Dose-Response Relationship \\
\hline Humans & Individuals & Lifetime cancer risk & Established relationship \\
\hline Ecological & $\begin{array}{l}\text { Scenario dependent: could be } \\
\text { populations, communities, or } \\
\text { ecosystems }\end{array}$ & $\begin{array}{l}\text { Species dependent: could be } \\
\text { increased mortality, decreased } \\
\text { fecundity, other sub-lethal } \\
\text { effects }\end{array}$ & $\begin{array}{l}\text { Unknown in many cases: chronic } \\
\text { low-levels of radiation exposure } \\
\text { only, possibly radiation exposure } \\
\text { mixed with other toxins? }\end{array}$ \\
\hline
\end{tabular}

Table 2. Data availability for chronic and external gamma radiation effects.

\begin{tabular}{|c|c|c|c|c|}
\hline Species & Morbidity & Mortality & Reproductive Capacity & Mutation \\
\hline Amphibians & Few & None & None & Few \\
\hline Aquatic Invertebrates & Available & Few & Few & Few \\
\hline Aquatic Plants & Few & Few & None & None \\
\hline Bacteria & Few & None & None & None \\
\hline Birds & None & None & Available & Few \\
\hline Crustaceans & Few & Few & Few & None \\
\hline Fish & Available & Few & Available & Available \\
\hline Fungi & Few & None & None & None \\
\hline Insects & Available & Few & Few & Few \\
\hline Mammals & Available & Available & Available & Few \\
\hline Moss/Lichens & Few & None & None & None \\
\hline Plants & Available & Available & Available & Available \\
\hline Reptiles & None & None & None & Few \\
\hline Soil Fauna & Few & Few & None & Few \\
\hline Zooplankton & Few & None & Few & None \\
\hline
\end{tabular}


a peer reviewed article, 210 were from institutional publications, 140 had no listed reference, and 49 were derived during the creation of the model by the authors [9]. Of the data required to build the model, 35\% were either not sourced, or inferred by the authors of the performance assessment.

There are ways to fill data gaps for site assessments. Collection of samples of opportunity from locations representative of the site can fill gaps for specific locations $[10,11]$. Collection efforts, along with, rapid processing and analysis can provide data that is accurate for the site and applicable.

\subsection{Distribution of Information}

When transfer (e.g., concentration ratio) data is collected, there are no guidelines for filling in data gaps. What is collected is at the discretion of the team of researchers completing the study. The possibilities for research are open ended, but tend to be focused in specific directions towards certain elements and species.

There are two ways to consider how data is available, the first is element specific. IAEA Technical Document 1616 [12] provides a sense of the distribution of element specific transfer data for longer lived artificial radionuclides. Of the 9370 records for root transfer, roughly sixty percent provided data on cesium, strontium, or cobalt. The other 36 elements shared the remaining forty percent though most sources quantified manganese, zinc, americium, neptunium, and curium. The focus is similar in tropical and subtropical environments, though fewer radionuclides are cataloged. Of the data available, $47 \%$ is for cesium and strontium, $21 \%$ is for naturally occurring radionuclides, $16 \%$ provides data on cobalt, zinc, and manganese, with the remaining data pertaining to other radionuclides. Naturally occurring radionuclides show similar trends with the focus being on uranium and radium with other elements having sparse associated transfer data.

The second methodology for transfer is by animal, but this too has data gaps. The number of listed references for human protein and milk sources was categorized in IAEA Technical Document 1616 [12]. The numbers of references for 37 elements are shown in the following table (Table 3) for beef, cow milk, sheep meat and milk, goat meat and milk, pork, poultry, eggs. Looking at the data, it is again apparent that cesium and strontium are better characterized in beef and cow milk than other elements. Iodine transfer through cow milk is also well characterized. But when looking at meat and milk products from goat and sheep, meats that are eaten throughout the world, but not considered part of the core western diet.

The amount of data for plants and animals that are not art of the western food chain is even sparser. A review of pasture grazers by Brown et al. [13] showed that reindeer transfer factors accounted for more than 80 percent of the available values. Similar notes have been made on the availability of transfer factors for birds.

From both conceptual methodologies, the IAEA considers the amount of data for cesium and strontium to be acceptable and nearly adequate for uranium, radium, manganese and cobalt. These six elements have more than 500 listed references available; the other elements considered have not been studied to the same extent and do not have enough data points to be considered sufficiently categorized.

\section{Determining Dose to Non-Human Biota: The Development of Computational Voxel Phantoms}

Several approaches have been developed, tested and compared for the computation of radiation dose in non-human biota. The ICRP has developed a comprehensive approach that includes the use of Reference Animals and Plants (RAPs) for the assessment of dose to NHB.

ICRP's current approach to dosimetry calculations for NHB relies on simplified organism geometry. Organisms are modeled as ellipsoids made of homogeneous ICRU four-component soft tissue [14]. Some models also contain simple ellipsoidal organs that serve as targets for dosimetric calculations [15]. These rudimentary models are used to generate absorbed fractions that are in turn used to calculate dose conversion factors (DCFs) from radionuclides that are distributed uniformly throughout the organism. There are two scenarios that require considerations beyond that available with homogeneous models. The first is when comparing full body average dose rates for homogeneous and non-homogeneous distributions of incorporated radionuclides and assessments of the uncertainties of the whole body doses due to those non-homogeneous sources. The second is when it is necessary or prudent to estimate organ dose rates form radionuclides that partition heterogeneously.

Voxel models are three dimensional models created from radiological imaging modalities (e.g. computed tomography and magnetic resonance imaging). These models allow radioecologists to calculated organ-specific DCFs from heterogeneously distributed radionuclides. Voxel models are more robust and easily defendable than the previously used ellipsoidal models.

Figure 1 shows the procedure for the creation of voxel phantoms. First, the organism of interest is obtained, and imaged using CT or MRI. The scans are loaded into software (3D Doctor in the case of the crab, flatfish, trout, bee, and earthworm that have been created to date) that allows the user to manipulate the images. Organs and other structures or tissues of interest are segmented, and 
Table 3. Number of available transfer coefficients for certain proteins and milk sources, data from IAEA Technical Document 1616 [14].

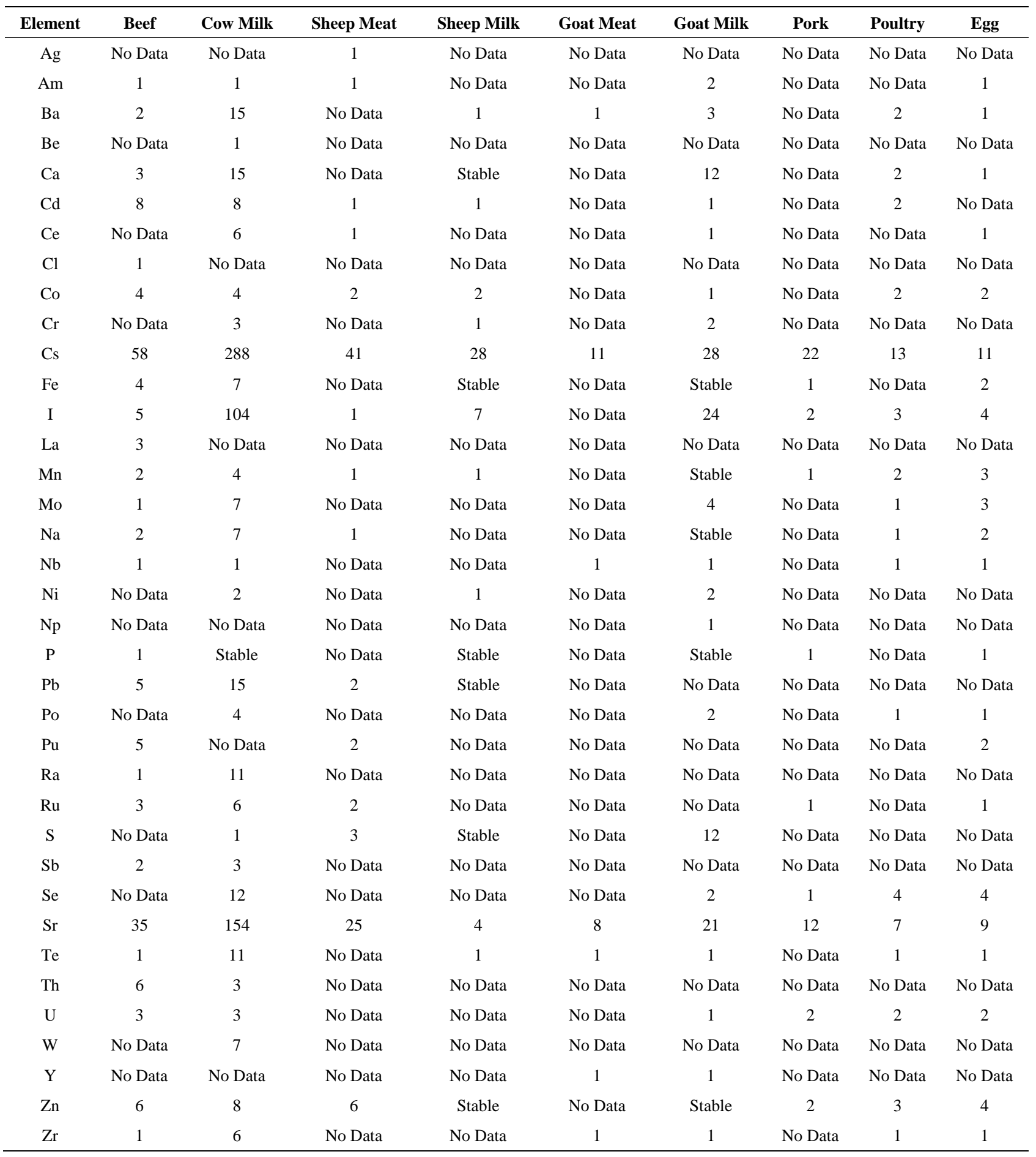

a 3-dimensional model is created. 3D Doctor allows for the export of a boundary file, which specifies the coordinates of each segmented tissue on a three dimensional matrix grid. This file is imported into a program created by the Human Monitoring Laboratory called Voxelizer [16]. Finally, a lattice geometry is imported into the
Monte-Carlo N-Particle transport code, where absorbed fractions (AF; a unit-less number that quantifies the amount of energy deposited in a target organ from a source organ). The AF values are then used in radiation dose or DCF calculations, coupled with environmental concentration data. This dose calculation informs the 


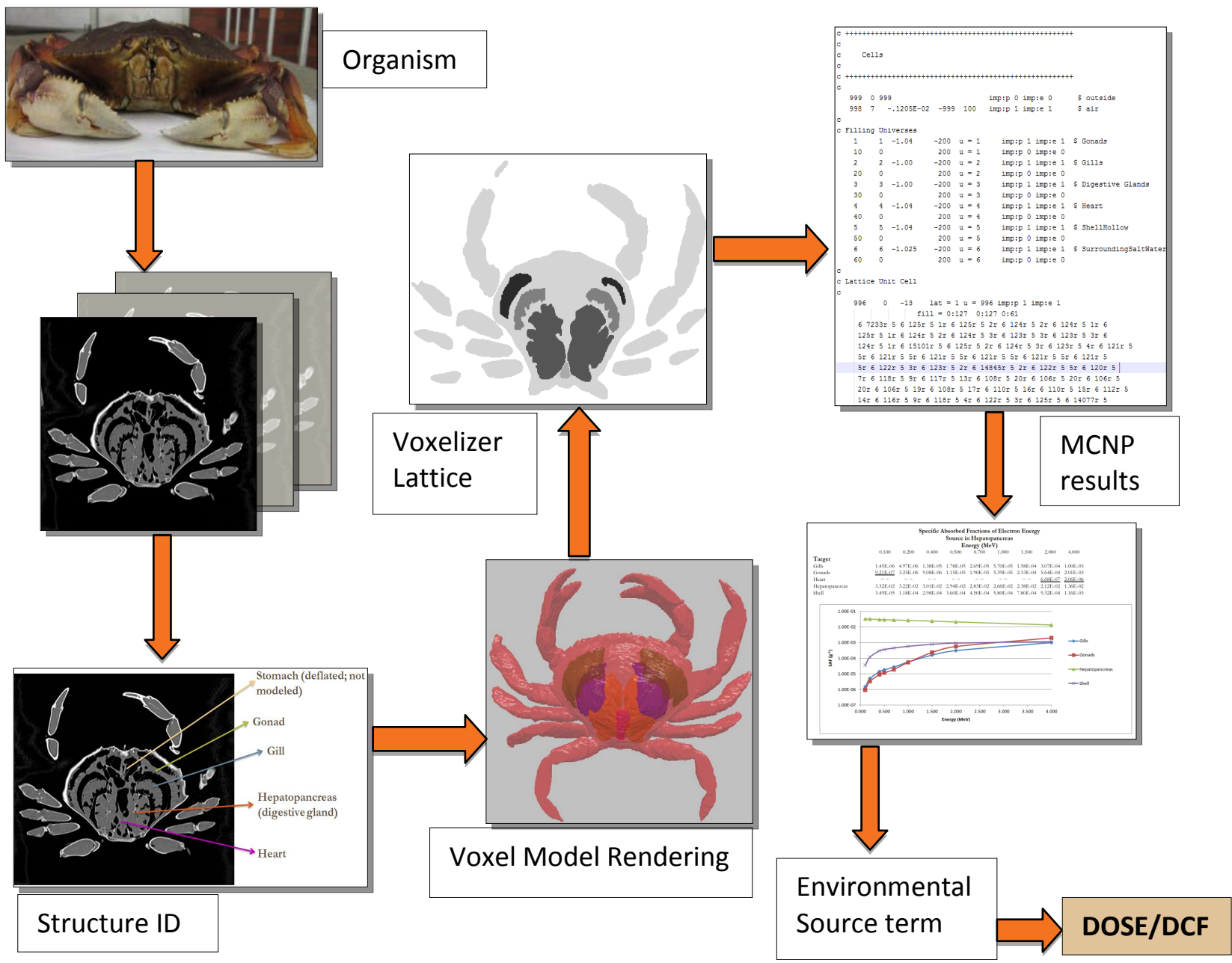

Figure 1. Creating voxel phantoms.

decision-making process, such that environmental remediation, removal of wildlife, or other actions deemed necessary can be taken.

\section{Implications for Nuclear Waste and Site Decommissioning Policies}

\subsection{Biosphere Models}

Performance assessments comprise the formal means by which the long-term safety of nuclear waste repositories is evaluated. In its peer review of the biosphere modeling program of the US Department of Energy's Yucca Mountain site characterization project, the International Atomic Energy Agency states that an essential component of a performance assessment is the development and application of a methodology for assessing the potential impact of any future releases of radionuclides that may reach the surface environment, i.e. the biosphere [17]. Efforts to predict radiological doses to future human populations resulting from long-term geological disposal of radioactive wastes rely heavily on modeling software.
Modeling programs have been designed to predict movement of radionuclides in future environments (up to $1 \times 10^{6}$ y) [18-20]. Many performance assessments incorporate a scenario of future human inhabitants living near a waste repository and irrigating crops with groundwater contaminated with radioactive isotopes in the absence of major geological disturbance or human intrusion into the repository [21].

Broadly speaking, the modeling process for radioactive waste internment or site decommissioning involves 1) construction of a conceptual model that describes the system and includes each of the important processes and their couplings, 2) translation of the conceptual model into a mathematical model and coding it into a computer program, 3) verification of the numerical correctness of the code, and 4) validation of the code's applicability to the repository system to assess its predictive capabilities [22]. A sequential chain of codes is then constructed to model waste canister corrosion, waste dissolution, nearfield diffusive transport of radionuclides, far-field diffusive transport of radionuclides, radionuclide release to 
the biosphere, and uptake of radionuclides by humans, plants, or animals.

The last two components, release of radionuclides to the biosphere and their subsequent uptake by biota, are most relevant to the field of radioecology. Biosphere models must consider 1) radionuclide transport through many food chain pathways, such as deposition on soil and vegetation via irrigation water; 2) crop interception and retention; 3 ) radionuclide accumulation in soils as a result of long-term deposition by irrigation; 4) radionuclide leaching from the soil and retention mechanisms in root zones; 5) re-suspension of contaminated soil onto vegetation; 6) soil-to-plant uptake via roots; 7) transfer of radionuclides from feed to animal products; and 8) food ingestion rates of humans [23].

Although they are highly complex, these models by necessity include hypotheses, assumptions, and simplifications. Biosphere models are generally based on empirically determined bio-concentration factors, which predict radionuclide concentrations in plants and animals based on their concentrations in the environment (soil, water) or an animal's diet. Concentration ratio (CR) is the ratio of radionuclide concentration in plant or animal tissue to the radionuclide's concentration in the surrounding medium (soil, water). Transfer coefficients, also known as transfer factors, relate radionuclide concentrations in an animal's diet to radionuclide concentrations in foods produced from the animal.

The most minimal acceptable model of radionuclide uptake by vegetation is illustrated by Robertson et al. in their review of plant and animal transfer factors used in performance assessment models [23]. The model contains two components: the plant uptake of radionuclides deposited on plant material above ground, and plant uptake of radionuclides through roots. Equation (1) below shows how concentration of a radionuclide from deposition is calculated for a plant at the time of harvest. It is the sum of deposition of the radionuclide directly onto plant surfaces from the air, deposition from re-suspended soil material, and deposition from irrigation water:

$$
\begin{aligned}
\mathrm{C}_{\mathrm{dci}}\left(\mathrm{T}_{\mathrm{yr}}\right)= & {\left[\mathrm{R}_{\mathrm{id}} \Gamma_{\mathrm{dc}}+\mathrm{R}_{\mathrm{iw}} \Gamma_{\mathrm{wc}}\right.} \\
& \left.\left.+3.15 \mathrm{E} 7 \mathrm{C}_{\mathrm{ci}}\left(\mathrm{T}_{\mathrm{yr}}\right) \mathrm{RF}_{\mathrm{c}} \mathrm{V}_{\mathrm{di}} \Gamma_{\mathrm{dc}}\right)+\mathrm{R}_{\mathrm{wi}} *\left(\Gamma_{\mathrm{ic}} / \mathrm{M}_{\mathrm{c}}\right)\right] \\
& *\left[\mathrm{TV}_{\mathrm{c}} / \mathrm{B}_{\mathrm{c}} *\left(\left(1-\mathrm{e}^{-\lambda \mathrm{eiTgc} 2.74 \mathrm{E}-3}\right) / \lambda_{\mathrm{ei}}\right)\right]
\end{aligned}
$$

where:

$\mathrm{C}_{\text {dci }}\left(\mathrm{T}_{\mathrm{yr}}\right)=$ concentration of radionuclide $\mathrm{i}$ on plant type $\mathrm{c}$ at harvest from deposition processes for a one-year period $(\mathrm{Bq} / \mathrm{kg}$ wet weight)

$\mathrm{T}_{\mathrm{yr}}=$ one-year exposure period $(\mathrm{y})$

$\mathrm{R}_{\mathrm{id}}=$ constant dry deposition rate of radionuclide $\mathrm{i}$ $\left(\mathrm{Bq} / \mathrm{m}^{2} \mathrm{y}\right)$
$\mathrm{R}_{\mathrm{iw}}=$ constant wet deposition rate of radionuclide $\mathrm{i}$ $\left(\mathrm{Bq} / \mathrm{m}^{2} \mathrm{y}\right)$

$\Gamma_{\mathrm{dc}}=$ interception fraction from airborne dry deposition for plant type c (dimensionless)

$\Gamma_{\mathrm{wc}}=$ interception fraction for airborne wet deposition to plant type c (dimensionless)

$\mathrm{C}_{\mathrm{ci}}\left(\mathrm{T}_{\mathrm{yr}}\right)=$ average concentration of radionuclide $\mathrm{i}$ in farmland soil for crop type c for the current one-year period $\left(\mathrm{Bq} / \mathrm{m}^{2}\right)$

$\mathrm{RF}_{\mathrm{C}}=$ re-suspension factor for crop soil $\left(\mathrm{m}^{-1}\right)$

$\mathrm{V}_{\mathrm{di}}=$ deposition velocity of radionuclide $\mathrm{i}(\mathrm{m} / \mathrm{s})$

$\Gamma_{\text {ic }}=$ interception fraction for irrigation deposition to plant type c (dimensionless), generally equal to $\Gamma_{\mathrm{wc}}$

$\mathrm{M}_{\mathrm{c}}=$ fraction of the year irrigation takes place for plant type $\mathrm{c}$

$\mathrm{TV}_{\mathrm{c}}=$ translocation factor for plant type c (dimensionless)

$\mathrm{B}_{\mathrm{c}}=$ total standing biomass for plant type c ( $\mathrm{kg}$ wet weight $/ \mathrm{m}^{2}$ )

$\lambda_{\mathrm{ei}}=$ effective loss rate constant from plant surfaces representing weathering and radioactive decay for radionuclide i $\left(\mathrm{y}^{-1}\right)$

$\lambda_{\mathrm{ei}}=\lambda_{\mathrm{wi}}+\lambda_{\mathrm{I}}$

$\lambda_{\mathrm{wi}}=$ weathering rate constant for crops for radionuclide $\mathrm{i}\left(\mathrm{y}^{-1}\right)$

$\mathrm{T}_{\mathrm{gc}}=$ crop growing period for plant type c (days)

$3.15 \mathrm{E} 7$ = units conversion factor (sec/y)

$2.74 \mathrm{E}-3=$ units conversion factor $(\mathrm{y} / \mathrm{d})$

Equation (2) illustrates how concentration of a radionuclide in a plant due to root uptake is calculated:

$$
\mathrm{C}_{\mathrm{rci}}\left(\mathrm{T}_{\mathrm{yr}}\right)=\mathrm{C}_{\mathrm{ci}}\left(\mathrm{T}_{\mathrm{yr}}\right) \mathrm{B}_{\mathrm{vci}} * \mathrm{f}_{\mathrm{c}} * \mathrm{P}^{-1}
$$

where:

$\mathrm{C}_{\mathrm{rci}}\left(\mathrm{T}_{\mathrm{yr}}\right)=$ concentration of radionuclide $\mathrm{i}$ in crop type c from root uptake pathways for a 1-year period $(\mathrm{Bq} / \mathrm{kg}$ wet plant)

$\mathrm{B}_{\mathrm{vci}}=$ concentration ratio for plant type c $(\mathrm{Bq} / \mathrm{kg}$ dry plant per $\mathrm{Bq} / \mathrm{kg}$ dry soil)

$\mathrm{f}_{\mathrm{c}}=$ dry-to-wet ratio for plant type c (kg dry plant $/ \mathrm{kg}$ wet plant)

$\mathrm{P}=$ areal soil density ( $\mathrm{kg}$ dry soil $/ \mathrm{m}^{2}$ )

The total radionuclide concentration in the plant at the time of harvest is the sum of radionuclide contributions by deposition and root uptake is described by Equation (3):

$$
\mathrm{C}_{\text {hci }}\left(\mathrm{T}_{\mathrm{yr}}\right)=\mathrm{C}_{\mathrm{dci}}\left(\mathrm{T}_{\mathrm{yr}}\right)+\mathrm{C}_{\mathrm{rci}}\left(\mathrm{T}_{\mathrm{yr}}\right)
$$

where:

$\mathrm{C}_{\text {hci }}\left(\mathrm{T}_{\mathrm{yr}}\right)$ is the concentration of radionuclide $\mathrm{i}$ in plant type $\mathrm{c}$ at harvest for a one-year period $(\mathrm{Bq} / \mathrm{kg}$ wet plant), and other terms are as previously defined.

A cursory review of the equations for plant radionuclide uptake reveals the complexities inherent to evaluating radionuclide concentrations in crops. The equations 
describing radionuclide concentrations in animals used for foodstuffs are no less complex. Transfer factors are often element and species specific. For example, a transfer coefficient calculated for ${ }^{99} \mathrm{Tc}$ cannot be used interchangeably with one calculated for ${ }^{137} \mathrm{Cs}$, as these elements have different chemical and physiological properties. One cannot assume that a transfer coefficient calculated for ${ }^{90} \mathrm{Sr}$ in beef is applicable to ${ }^{90} \mathrm{Sr}$ in chicken. Calculation of transfer coefficients must also take into consideration each of the following variables: mode of absorption (gastrointestinal, inhalation, etc.); homeostatic control mechanisms that may cause variation in transfer coefficients over a wide range of conditions (for example, if calcium and strontium are under homeostatic control with regard to their concentrations in milk, estimates of strontium intake by the animal may not allow accurate determination of strontium concentration in the milk); equilibration of radionuclides in animal tissues; the effects of a radionuclide's chemical form, generally associated with solubility, on rates of absorption; isotopic effects of radionuclides lacking stable isotope carriers (such as technetium and plutonium); interference of dietary components such as fiber; age of the animal; variations in geography; and other variables such as soil ingestion by the animal [23].

\subsection{Missing Data}

In the absence of solid experimental, observational, or theoretical support, performance assessment model parameters are generally selected to yield conservative results. Erring on the side of caution is preferable to underestimating dose to biota; however, this approach almost certainly overestimates risk in some cases. With regard to waste repository performance assessments, regulatory decisions and allocation of resources should rely on experimentally determined model input values whenever possible. Recent investigations have revealed significant data gaps in the parameters used for modeling radionuclide uptake by both plants and animals [9,24,25]. Concentration ratios and transfer coefficients for ${ }^{137} \mathrm{Cs}$ and

${ }^{90} \mathrm{Sr}$ have been experimentally determined for many plant and animal species, due to the predominance of these isotopes in releases from atmospheric testing and events at Chernobyl in 1986 and the Fukushima Daiichi plant in 2011. However, data for determining biosphere concentrations of many other components of high-level nuclear waste are either incomplete or lack empirical support.

Figure 2 and Table 2 show the number of available data sources for concentration ratios and transfer factors [14]. In their 2011 review of the parameters selected for a recent performance assessment, Higley et al. determined that of the 538 parameters examined, 139 (26\%) referenced at least one peer-reviewed article. 210 (39\%) referenced an institutional publication. 140 (26\%) had no references, and 49 (9\%) were justified or derived internally by the case study's authors. Gaps in compendia of experimentally determined values have not prevented predictions for radionuclide transfer among wide-ranging species and environments. This is problematic, because such predictions may be made using data obtained from chemical analogues (e.g. iodide in place of chloride based on both being halogens) or altogether dissimilar chemical species. In other cases, informed judgment regarding use of data is relegated to appendices, and the uncertainty surrounding use of estimates or surrogates may go unacknowledged.

Figure 3 is output from the Yucca Mountain Project Performance Assessment (YMPPA), which shows the annual predicted dose contributions from various radionuclides up to one million years following repository closure under nominal conditions [26]. Major contributors to biosphere concentrations one million years post repository closure are ${ }^{99} \mathrm{Tc},{ }^{237} \mathrm{~Np},{ }^{233} \mathrm{U},{ }^{129} \mathrm{I},{ }^{242} \mathrm{Pu}$, and ${ }^{36} \mathrm{Cl}$. These radionuclides are also predicted to contribute the majority of dose to a reasonably maximally exposed individual (RMEI) over the same time frame.

A great deal of work has been done over the past ten years to establish site-specific concentration ratios and transfer factors for many of the long-lived radionuclides identified in the YMPPA. Napier et al. performed soil-toplant uptake studies for ${ }^{99} \mathrm{Tc},{ }^{238} \mathrm{Pu}$, and ${ }^{241} \mathrm{Am}$ using soils and groundwater collected from sites in the northwest, southeast, and southwest United States [27]. Concentration ratios were determined for onions, potatoes, alfalfa, and corn grown in each soil type and irrigated with groundwater from the corresponding source. Comparisons between the site-specific concentration ratios and their generic counterparts contained in existing compendia led the authors to conclude that "Generic concentration ratios are of limited use in site-specific dose analysis”. In addition, the assumption that a plant will exhibit linear uptake of a nutritional element or its analog may not be valid. For example, CRs determined for ${ }^{99}$ Tc were very high —as much as several hundred, depending on the combination of soil and plant. Technetium can mimic sulfur physiologically, and in its most common far-field oxidation state (+7), it is highly water soluble. Regional variations in soil-to-plant uptake must be addressed with site-specific determinations of CR and transfer factors in order to reduce uncertainty in dose predictions. Soil-toplant uptake studies performed for ${ }^{237} \mathrm{~Np}$ and ${ }^{125} \mathrm{I}$ in alfalfa, corn, and potatoes led to similar conclusions [19]. Soil and groundwater samples were obtained from sites in the northwest, southeast, and southwest United States and used to grow crops of each type. Significant differences in iodine uptake were observed between plant species and crop types. The CRs generated by the study for both ${ }^{237} \mathrm{~Np}$ and ${ }^{125}$ I were substantially larger than the ge- 
After TECDOC 1616: Number of Records of Soil: Plant Transfer Factors for Artificial Radionuclides

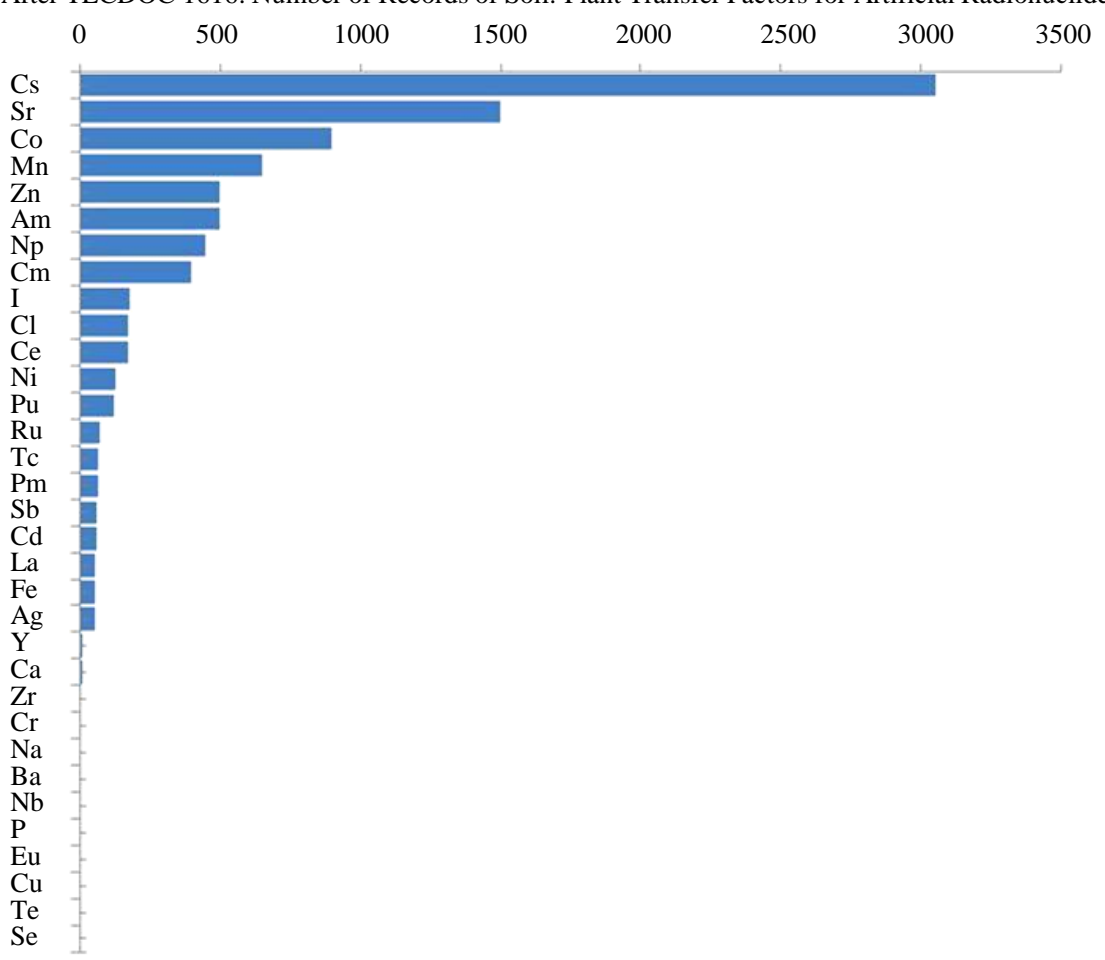

Figure 2. Data sources for determining concentration ratio by element (data from IAEA TECDOC 1616) [14].

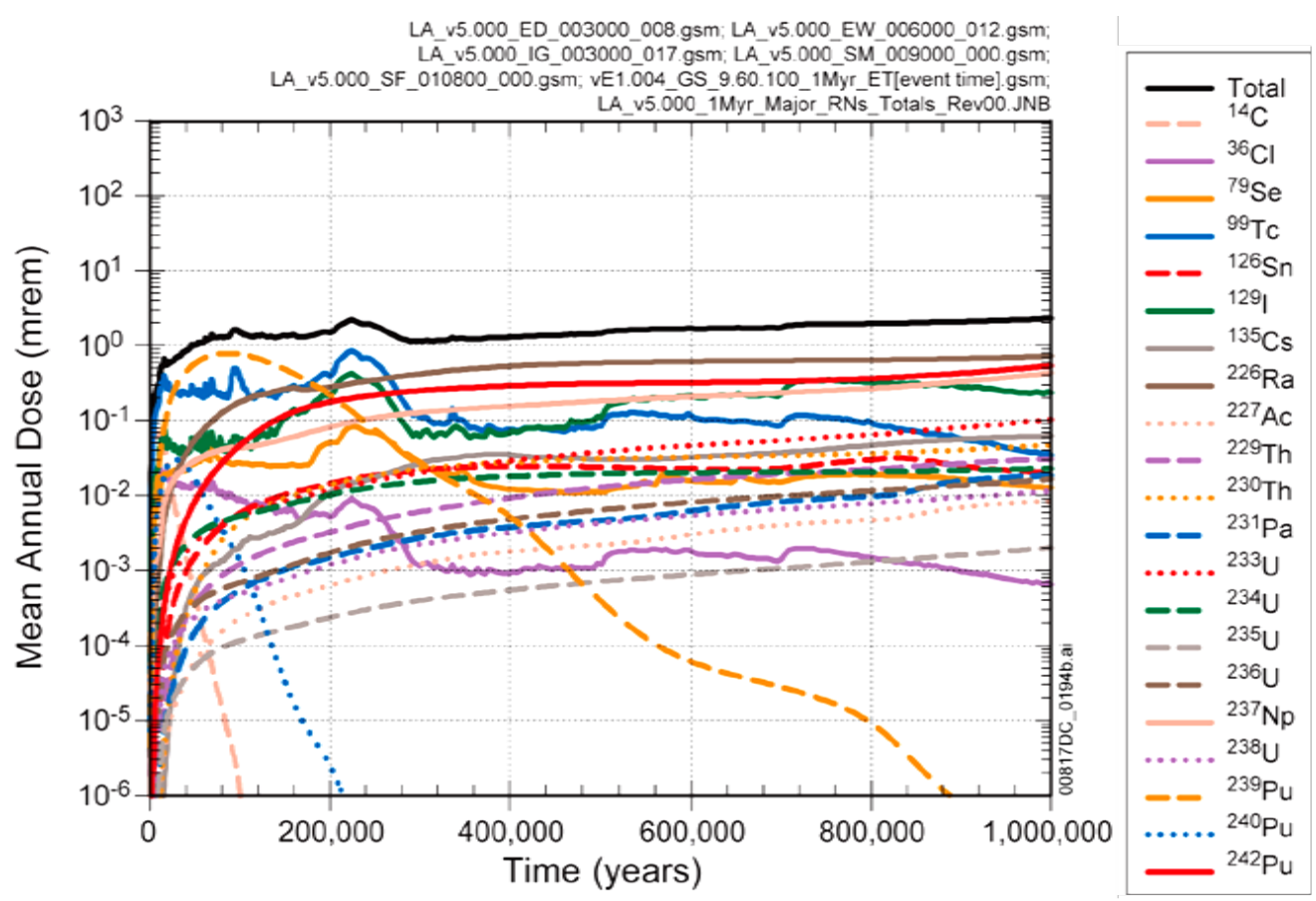

Figure 3. Contributions to total mean annual dose to a RMEI from individual radionuclides over $1 \times 10^{6}$ years, based on nominal conditions (no geological disturbance or human intrusion into the repository). A RMEI would rely exclusively on contaminated groundwater pumped to the surface for irrigation of crops and watering of livestock. Data from [28].

neric CRs typically used in performance assessments. Both studies underscore the requirement of site-specific data for meaningful dose analysis near waste repositories and decommissioned sites.

${ }^{36} \mathrm{Cl}$ is a major isotope of concern in the YMPPA, and a close examination of CR and TF literature for ${ }^{36} \mathrm{Cl}$ illu- 
strates some of the problems associated with many model input values currently in use. This isotope is a neutron activation product of ${ }^{35} \mathrm{Cl}$, which is present in small quantities in graphite, cladding, nuclear fuel, and other sources. It is persistent, with a half-life of just over 300,000 years, and it is highly mobile in the environment as chloride anion. In a comprehensive literature review for this isotope, no studies were found that addressed foliar interception of ${ }^{36} \mathrm{Cl}$ by crops irrigated with groundwater containing it [28]. Only scattered data was obtained for foliar absorption of ${ }^{36} \mathrm{Cl}$. The data that was obtained was of questionable pedigree. In "A Compendium of Transfer Factors for Agricultural and Animal Products" (PNNL-13421), Staven et al. list a CR of 70 for chlorine in leafy vegetables based on root uptake [25]. The primary reference given for this value is an older report that indicates the $\mathrm{CR}$ was obtained indirectly by assuming an average chloride soil concentration of 100 ppm, while the reported range of concentrations in plants was 2000 to 23,000 ppm [29]. This estimate was included because the values calculated based on empirical data were judged to be unusable. A CR of 2.1 in sweet clover was obtained from Furr et al. [30], while other studies report CR values between 18 and 377, depending on soil and plant type [31,32].

The compendia of generic concentration ratios and transfer factors currently in use have significant gaps and inadequacies. For many of the longest-lived components of nuclear waste, very little data exists. Generic CR and $\mathrm{TF}$ values that are available for these radionuclides are frequently characterized by high uncertainties and dubious pedigrees. Experimentally determined site-specific $\mathrm{CR}$ and TF values for several sites in the US have been published recently. While their uncertainties are generally lower, they are by definition best suited for site-specific modeling. Significant differences in uptake result from physical and chemical differences among soils and water sources. Dose assessments performed with modeling software-whether they are for waste repositories, decommissioned sites, or emergency response-should rely on high-quality and experimentally determined input values. Much work remains to be done to increase the quantity and quality of CR and TF data used in modeling applications. This can only be accomplished with robust radionuclide uptake studies.

\section{Why Does It All Matter?}

Ultimately, to ensure protection of the ecosystems which receive anthropogenic radioactivity releases, we must have the tools to determine what doses are being delivered and the knowledge of what doses produce the endpoints of concern.

How well can we determine absorbed dose to NHB that exist in spatially and temporally varying radiation fields? The endpoints of concern are a matter of two variables: how sensitive is a given organism, and what level of deleterious effects is acceptable? The most sensitive taxa (e.g. mammals, birds) have many regulations in place that focus on preventing individual level effects. Sessile organisms are among the easiest organisms for which to calculate dose. However, they are also generally far more radio-resistant than other organisms, with the exception of trees (see Figure 4). This means that to meet guidelines in a radioecology protection program with endpoints similar to other environmental protection programs, we must be able to accurately determine doses and dose rates for mobile organisms moving through a spatially (and often, temporally) varying radiation field, with likewise varying contamination levels.

This introduces challenges that to date have been addressed to some degree. The simplest of these operate

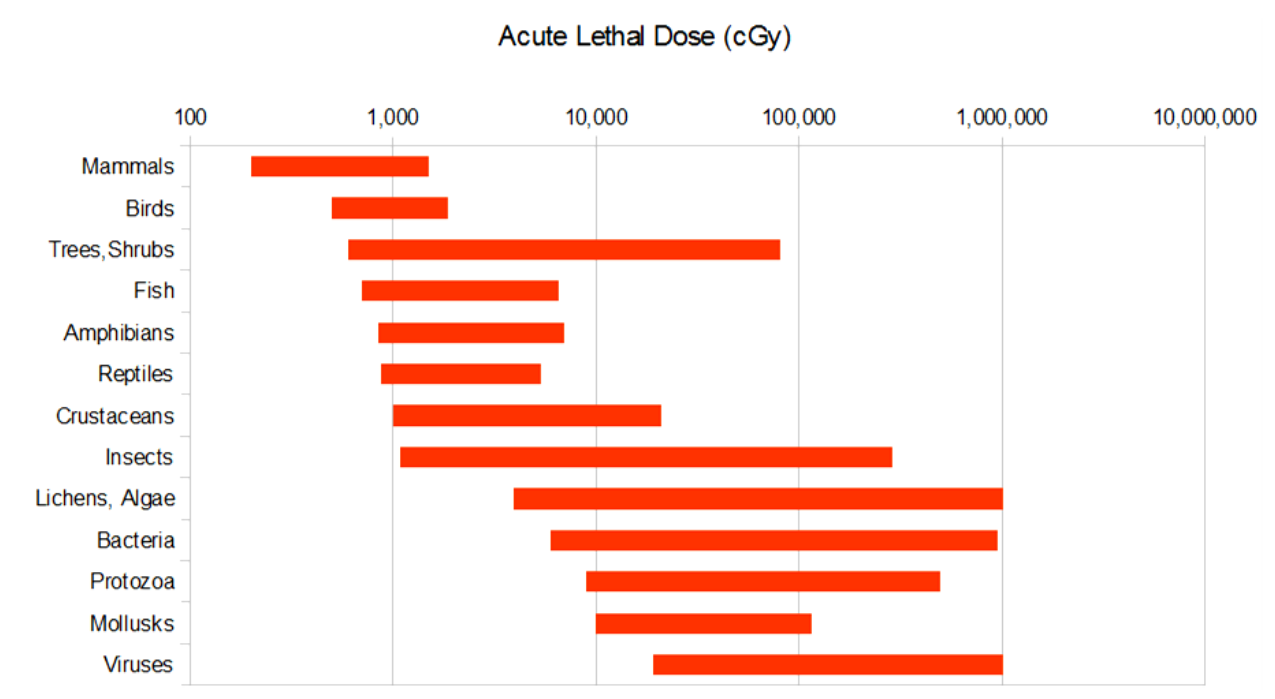

Figure 4. Ranges of observed lethal dose thresholds for various taxa in cGy [1]. 
simply via CRs as discussed earlier, to convert a soil measurement into estimated contamination levels of all organisms in the vicinity. This simplified approach is easily extended to apply to temporal variation, as organisms are simply assumed to instantaneously reach the published CRs. With the orders of magnitude variation in CRs and the need for site-specific calculations, this approach leaves such a great deal of uncertainty that translates into far more stringent regulations on environmental contamination than may truly be necessary to protect the ecosystem in question.

The next higher approach is to apply a network model for the food web and various medium-to-organism transfers. This is ideal for temporal variability as the transfer model already incorporates rate terms. The POSEIDONR model [30] has accurately predicted organism concentrations using this approach for the area around Fukushima, Japan, including the increased biota concentrations in 2012 that surprised many other researchers. Spatial variability here is addressed by using physical compartments large enough that all organisms may be treated as sessile with respect to that compartment. Mammals and birds, being the likely drivers of endpoints of concern, throw a wrench into the works with the large-compartment approach. The large spatial movements associated with many birds, marine mammals, and some terrestrial mammals extending beyond the range where physical compartments are still small enough to describe the physical processes that produce spatial contamination patterns. In the marine environment, even reptiles and fish can have spatial movements greater than the size of features in the radiation or contamination distribution. When we speak of reproductive impacts, fish may be the most sensitive taxa in the marine environment [33], making a solution to their migration patterns especially pertinent to marine ecosystem protection.

Presently, our regulatory restrictions are based more loosely on population level effects, which introduce considerable leeway in the level of spatial variability detail we need. Rather than needing to describe movement patterns of individuals, we simply need a spatial occupation factor description. This is much easier to determine via routine surveys of the number of organisms present at each site, whereas individual level protection necessitates individual level movement description (e.g. radio tag studies). Determining external doses through such an approach is entirely feasible, but internal dose assessment is more challenging. CRs have large uncertainties but are easy to apply, which is why they remain a part of practices today. Food-web transfer models with spatial patterns for each species in the web would necessitate models that track spatially distinct communities that may be grazed by more mobile predators. However, with data on diet, transfer factors, and biological half-lives such an approach is computationally possible. Doing so for an individual-level protection scheme would not, but a combination of these approaches (individual level for species of concern, population level for other food web components) may very well be with sufficient movement pattern description, be in the form of a function or as a randomly sampled collection of real-life recorded spatial movements.

Our measure of dose to wildlife remains fairly simplistic. In humans, we have substantial medical data upon which to weight exposures to different organs as well as weight different types and energies of radiation. Human protection focuses on stochastic effects (mainly cancer) associated with acute exposures. NHB protection depends on chronic exposures that produce largely deterministic effects. While there has been much written on the topic, we do not yet have a consensus on the appropriate NHB weighting factors to use for different radiation types and energies [34].

The field of radioecology is rapidly expanding, its relevance to humans becoming more apparent as humans continue to rely on the use of ionizing radiation to improve their lives. From handling spent fuel or decommissioning of former nuclear power plants to medical isotopes and industrial radiography sources, we have a multitude of potential environmental consequences to consider from these uses. Radioecology aims to ensure we reap all the uses we've found for these technologies without sacrificing related ecosystems in the process.

\section{REFERENCES}

[1] F. W. Whicker and V. Schultz, "Radioecology: Nuclear Energy and the Environment," CRC Press, Boca Raton, 1982.

[2] ICRP, "Recommendations of the International Commission on Radiological Protection," Annals of the ICRP, Vol. 1, No. 3, 1977, ICRP Publication 26.

[3] N. Ryabokon and R. Goncharova, “Transgenerational Accumulation of Radiation Damage in Small Mammals Chronically Exposed to Chernobyl Fallout," Radiation and Environmental Biophysics, Vol. 45, No. 3, 2006, pp. 167-177. http://dx.doi.org/10.1007/s00411-006-0054-3

[4] A. P. Moller and T. A. Mousseau, "Species Richness and Abundance of Forest Birds in Relation to Radiation at Chernobyl,” Biology Letters, Vol. 3, No. 5, 2007, pp. 483-486. http://dx.doi.org/10.1098/rsbl.2007.0226

[5] A. P. Møller and T. A. Mousseau, "Reduced Abundance of Insects and Spiders Linked to Radiation at Chernobyl 20 Years after the Accident,” Biology Letters, Vol. 5, No. 3, 2009, pp. 356-359. http://dx.doi.org/10.1098/rsbl.2008.0778

[6] J. Garnier-Laplace, S. Geras'kin, C. Della-Vedova, K. Beaugelin-Seiller, T. G. Hinton, A. Real and A. Oudalova, "Are Radiosensitivity Data Derived from Natural Field Conditions Consistent with Data from Controlled Expo- 
sures? A Case Study of Chernobyl Wildlife Chronically Exposed to Low Dose Rates,” Journal of Environmental Radioactivity, Vol. 121, 2013, pp. 12-21. http://dx.doi.org/10.1016/j.jenvrad.2012.01.013

[7] IAEA, “TecDoc-1109 Use of Natural Analogues to Support Radionuclide Transport Models for Deep Geological Repositories for Long Lived Radioactive Wastes,” Vienna, 1999.

[8] F. Whicker and V. Schultz, "Radioecology: Nuclear Energy and the Environment V. 2,” CRC Press, Boca Raton, 1982.

[9] K. Higley, D. Bytwerk and E. Houser, “Transparency in the Selection of Biosphere Parameters for Geological Disposal Systems,” Waste Management Conference, Phoenix, 27 February-3 March 2011.

[10] K. A. Higley, "Estimating Transfer Parameters in the Absence of Data," Radiation and Environmental Biophysics, Vol. 49, No. 4, 2010, pp. 645-656. http://dx.doi.org/10.1007/s00411-010-0326-9

[11] J. Napier, "Establishment of Concentration Ratios for Riparian and Shrub Steppe Areas of the Eastern Washington Columbia Basin,” Oregon State University, Corvallis, 2013.

[12] IAEA, “TecDoc-1616 Quantification of Radionuclide Transfer in Terrestrial and Freshwater Environments,” Vienna, 2009.

[13] J. Brown, P. Strand, A. Hosseini and B. Peer, "Handbook for Assessment of the Exposure of Biota to Ionising Radiation from Radionuclides in the Environment,” 2003.

[14] ICRU, "Photon, Electron, Proton, and Neutron Interaction Data for Body Tissues. ICRU Report 46,” International Commission on Radiation Units, Bethesda, 1992.

[15] ICRP, "Environmental Protection: The Concept and Use of Reference Animals and Plants," Annals of the ICRP, Vol. 38, No. 4-6, 2008, ICRP Publication 108.

[16] G. H. Kramer, K. Capello, A. Chiang, E. Cardenas-Mendez and T. Sabourin, "Tools for Creating and Manipulating Voxel Phantoms," Health Physics, Vol. 98, No. 3, 2010, pp. 542-548. http://dx.doi.org/10.1097/HP.0b013e3181c34ced

[17] IAEA, "An International Peer Review of the Yucca Mountain Project TSPA-SR,” Vienna, 2002.

[18] D. W. Wu, M. A. Wasiolek, A. J. Tappen, J. J. Rautenstrauch and K. R. Smith, "ERMYN: Environmental Radiation Model for the Yucca Mountain, Nevada,” Las Vegas, 2002.

[19] B. A. Napier, R. J. Fellows and K. M. Krupka, "Radionuclide Behavior in Soils and Soil-To-Plant Concentration Ratios for Assessing Food Chain Pathways (NUREG/CR-7120),” US Nuclear Regulatory Commission, Washington DC, 2012.

[20] S. Kamboj, D. LePoire, E. Gnanapragasam, B. Biwer, J. Cheng, J. Arnish, C. Yu and S. Y. Chen, "Probabilistic Dose Analysis Using Parameter Distributions Developed for RESRAD and RESRAD-BUILD Codes (NUREG/ CR-6676)," US Nuclear Regulatory Commission, Washington DC, 2000.

[21] EPRI, "EPRI Yucca Mountain Total System Performance Assessment Code (IMARC) Version 10: Model Descrip- tion and Analyses,” Palo Alto, 2009.

[22] W. Miller, R. Alexander, N. Chapman, I. McKinley and J. Smellie, "Geological Disposal of Radioactive Wastes and Natural Analogues: Lessons from Nature and Archaeology,” Waste Management Series, Volume 2, Elsevier, Amsterdam, 2000.

[23] D. A. Robertson, D. A. Cataldo, B. A. Napier, K. M. Krupka and L. B. Sasser, "Literature Review and Assessment of Plant and Animal Transfer Factors Used in Performance Assessment Modeling (NUREG/CR-6825),” US Nuclear Regulatory Commission, Washington DC, 2003. http://dx.doi.org/10.2172/1024566

[24] IAEA, "IAEA-TECDOC-1616: Quantification of Radionuclide Transfer in Terrestrial and Freshwater Environments for Radiological Assessments,” Vienna, 2009.

[25] L. H. Staven, B. A. Napier, K. Rhoads and D. L. Strenge, "A Compendium of Transfer Factors for Agricultural and Animal Products (PNNL-13421),” US Nuclear Regulatory Commission, Washington DC, 2003. http://dx.doi.org/10.2172/15010186

[26] Sandia National Laboratories, "Total System Performance Assessment Model/Analysis for the License Application,” Las Vegas, 2008.

[27] B. A. Napier, R. J. Fellows and K. M. Krupka, "Soil-toPlant Concentration Ratios for Assessing Food-Chain Pathways in Biosphere Models (NUREG/CR-6941)," US Nuclear Regulatory Commission, Washington DC, 2007. http://dx.doi.org/10.2172/926965

[28] D. Bytwerk, "Foliar Interception and Uptake of 36Cl by Crops,” Oregon State University, Corvallis, 2011.

[29] C. F. Baes, R. D. Sharp, A. L. Sjoreen and R. W. Shor, "A Review and Analysis of Parameters for Assessing Transport of Environmentally Released Radionuclides through Agriculture: A Review and Analysis of Parameters for Assessing Transport of Environmentally Released Radionuclides through Agriculture,” 1984.

[30] A. K. Furr, T. F. Parkinson, C. L. Heffron, J. T. Reid, W. M. Haschek, W. H. Gutenmann, C. A. Bache, L. E. St. John and D. J. Lisk, "Elemental Content of Tissues and Excreta of Lambs, Goats, and Kids Fed White Sweet Clover Growing on Fly Ash,” Journal of Agricultural and Food Chemistry, Vol. 26, No. 4, 1978, pp. 847-851. http://dx.doi.org/10.1021/jf60218a004

[31] V. Kashparov, C. Colle, S. Levchuk, V. Yoschenko and N. Svydynuk, "Transfer of Chlorine from the Environment to Agricultural Foodstuffs," Journal of Environmental Radioactivity, Vol. 94, No. 1, 2007, pp. 1-15. http://dx.doi.org/10.1016/j.jenvrad.2006.12.006

[32] V. Kashparov, C. Colle, S. Levchuk, V. Yoschenko and S. Zvarich, "Radiochlorine Concentration Ratios for Agricultural Plants in Various Soil Conditions," Journal of Environmental Radioactivity, Vol. 95, No. 1, 2007, pp. 10-22. http://dx.doi.org/10.1016/j.jenvrad.2007.01.008

[33] T. G. Hinton, R. Alexakhin, M. Balonov, N. Gentner, J. Hendry, B. Prister, P. Strand and D. Woodhead, "Radiation-Induced Effects on Plants and Animals: Findings of the United Nations Chernobyl Forum," Health Physics, Vol. 93, No. 5, 2007, pp. 427-440. 
http://dx.doi.org/10.1097/01.HP.0000281179.03443.2e

[34] D. B. Chambers, R. V. Osborne and A. L. Garva, "Choosing an Alpha Radiation Weighting Factor for Doses to Non-Human Biota,” Journal of Environmental Radioac- tivity, Vol. 87, No. 1, 2005, pp. 1-14.

http://dx.doi.org/10.1016/j.jenvrad.2005.10.009 